\title{
“Classe média”, Mobilização social e ação política em Portugal e no Brasil
}

ESTANQUE, Elísio. Classe média e lutas sociais: ensaio sobre sociedade e trabalho em Portugal e no Brasil. Campinas: Editora da Unicamp, 2015. 216 p.

Por

\section{Gustavo Casasanta Firmino}

Como seu título permite antever, o livro do sociólogo português Elísio Estanque é um ensaio comparativo entre a estrutura e evolução recente da sociedade de classes em Portugal e Brasil, cujo eixo gravitacional repousa sobre a temática da "classe média". A obra resulta de um trabalho desenvolvido em parceria com grupos de pesquisa e acadêmicos vinculados ao Departamento de Sociologia do Instituto de Filosofia e Ciências Humanas e ao Centro de Estudos Sindicais e de Economia do Trabalho, do Instituto de Economia, ambos da Unicamp. O texto é dividido em três partes principais.

Na primeira parte, o autor procura traçar um estado da arte do debate teórico clássico sobre a classe média, a partir de uma contraposição entre a teoria das classes, de origem marxiana e a teoria da estratificação social, derivada da junção entre a tradição positivista e a corrente liberal de matriz weberiana. Também são considerados diversos autores que, a partir dos anos 1950, voltaram sua atenção para a questão da classe média, em especial aqueles que buscaram estabelecer uma complementaridade entre o debate marxista e a problemática oriunda das teorias da estratificação.

1 Doutorando em Ciência Política na Universidade Estadual de Campinas (UNICAMP), Brasil.gucasasanta@gmail.com 
Advogando a necessidade de uma análise ao mesmo tempo objetiva e subjetiva, capaz de levar em conta aspectos materiais e simbólicos, Estanque avança a noção - pouco promissora, a nosso ver - de que não se trataria de uma classe no sentido rigoroso do termo, mas de uma mancha nebulosa e internamente diversificada entre "elites" e "povo" ou entre "classe dominante" e "trabalhadores manuais". Embora faça referência à existência de diferentes camadas socioprofissionais no interior da classe média, o conceito é mobilizado sempre no singular, enquanto equivalente de classe média assalariada.

A emergência da meritocracia, tecnocracia, burocracia, gestão e profissionalização de quadros, no bojo do fordismo do pós-Segunda Guerra, ensejaria o surgimento de uma sólida classe média, entendida como fator decisivo de coesão social nas formações onde vigeu o Welfare State. Estanque se contrapõe à visão - atribuída à "vulgata marxista" - segundo a qual a classe média assalariada emergente nas décadas de 1950 e 1960 seria sinônimo de passividade, individualismo e integração à ordem vigente, ressaltando sua capacidade conflitiva, negocial e reivindicativa (ativismo sindical). Nessa linha, destaca o fenômeno do "radicalismo de classe média" que estaria na base dos chamados "novos movimentos sociais", como o movimento estudantil dos anos 1960. Dialogando com as teses de Guy Standing, argumenta que os efeitos deletérios da globalização neoliberal, a partir da década de 1980, ensejaram o surgimento de um "precariado" que passou a incorporar largos segmentos da classe média em declínio, especialmente em países da Europa do Sul.

Na segunda parte, o autor discorre sobre a evolução da sociedade de classes em Portugal e no Brasil. No caso português, o período iniciado em fins dos anos 1960, com o declínio do salazarismo e a abertura do país à economia internacional possibilitaria o surgimento de novos setores da burguesia industrial, a retomada da atividade sindical por parte da classe trabalhadora, bem como o florescimento de segmentos de classe média, em especial os quadros técnico-profissionais. A Revolução dos Cravos, em 
abril de 1974, teria consolidado uma nova perspectiva de desenvolvimento, descortinando um processo que, sob muitos aspectos, aproximou Portugal dos padrões de vida vigentes na Europa desenvolvida. A globalização neoliberal e a retirada do Estado de setores como saúde, educação e segurança social impactou diretamente a situação econômico-social de setores médios como profissionais qualificados, técnicos e outros especialistas, quadro que se agrava a partir de 2009. Estanque apresenta uma análise dos dados sobre o aumento do endividamento das famílias, para o qual contribuiu a queda dos salários e a elevação dos juros, combinada com marcadores de evolução da desigualdade social no país. Chama atenção para o fenômeno da "pobreza envergonhada", num cenário onde um crescente contingente de trabalhadores qualificados de classe média, como professores, advogados e engenheiros, passaram a recorrer ao auxílio de organizações filantrópicas e caritativas. Assim, segmentos significativos da força de trabalho portuguesa, que detinham posição estável nas fileiras da classe média, passariam a integrar o precariado em função dos vínculos precários de trabalho e seguridade que possuem.

No caso brasileiro, ocorreria um fenômeno inverso. O país teria vivenciado uma viragem estrutural, a partir de2003, marcada pelo aumento do crescimento econômico e melhoria nos indicadores do mercado de trabalho. Todavia, os postos de trabalho criados se caracterizaram majoritariamente pelos baixos salários, baixa qualificação e alto grau de rotatividade, bem como pelo alto grau de rotatividade, sinais de um projeto desenvolvimentista eivado de indefinições. $\mathrm{O}$ autor aponta para a emergência de um precariado brasileiro que, apesar de não integrar a classe média tradicional, apresentaria algumas afinidades com ela, tais como a obtenção de recursos escolares, qualificação técnica e vinculação predominante ao setor de serviços, traços capazes de lhe conferir crescente heterogeneidade.

$\mathrm{Na}$ terceira e última parte do livro, Estanque coteja diversos movimentos, manifestações e redes de contestação sociopolíticas surgidos em escala global, potencializados pela crise financeira de 2009. Aborda desde 
o ciclo de protestos que tiveram lugar em países sul europeus, passando pela Primavera Árabe e movimentos como o dos Indignados na Espanha e o Occupy Wall Street. Identifica uma relação tensa e ambivalente entre as lutas do trabalho, essencialmente identificadas com o movimento operário e sindical e os "novos" movimentos sociais, referidos ao campo simbólico e cultural, bem como a ausência de um sentido estratégico comum e um projeto político claro. Destaca a existência de um grande contingente de jovens qualificados (e precarizados) de classe média nessas manifestações, imersas numa forte cultura de cyberativismo.

As manifestações da chamada "Geração à Rasca" (sinônimo de geração em apuro, sem perspectiva de futuro) iniciadas em 2011 e que se estenderam até 2013 teriam sido, em Portugal, a expressão desse contexto de protestos a nível global. Temas como desemprego, precariedade laboral, perda de direitos e a política de austeridade foram fortemente mobilizados por uma juventude à rasca majoritariamente oriunda dos setores médios da sociedade, de sorte que a nova dinâmica de ciclos de protestos no país lusitano estabelecia pontos de contato com modalidades tradicionais de mobilização, com destaque para a ação sindical.

Os discursos, atitudes e lógica reivindicativa observados durante os "levantes" de junho de 2013, no Brasil, teriam obedecido a uma dinâmica de classe média. Na leitura do sociólogo português, os protestos de junho contaram com forte presença tanto de uma juventude ligada aos estratos sociais e valores ideológicos de uma classe média instalada, quanto de jovens trabalhadores precarizados (vale notar, nesse caso, a menção aos protestos ocorridos na cidade do Rio de Janeiro). Embora negue à atual geração da força de trabalho brasileira emergente a condição de classe média, Estanque identifica nos seus padrões de gostos, subjetividades e orientações um horizonte de classe média, balizado pela expectativa de mobilidade social ascendente.

A tese central do livro diz respeito ao caráter politicamente ambivalente da classe média, capaz de assumir tanto posições conservadoras 
quanto progressistas e mesmo de mesclar, na ação coletiva, orientações de cunho individualista e meritocrático com as lutas sociais que protagoniza. Algumas aproximações e correlações feitas pelo autor sobre a composição social, motivações e sentido de diferentes mobilizações sociais que marcaram o início da segunda década do século XXI nos parecem frágeis, quando não abusivas. Tal traço da obra certamente se deve, pelo menos em parte, ao seu caráter ensaístico. 